Предраг Мутавџић

\title{
БАЛКАНСКО ПОЛУОСТРВО КРОЗ ПРИЗМУ ЕВРОПЕИЗАЦИЈЕ ИЛИ ЕВРОПА КРОЗ ПРИЗМУ БАЛКАНИЗАЦИЈЕ? ${ }^{1}$ (ПРИЛОГ ПРОУЧАВАњУ КУЛТУРНИХ ОДНОСА ИЗМЕЪУ БАЛКАНА И ЕВРОПЕ)
}

Западна Европа је почела да интензивно проучава и да упознаје Балкан тек од почетка 19. столећа, и то са различитих аспеката. Иако је Балкан, са једне стране, веома близак Европи - овде се, пре свега, узимала у обзир географска близина, увидело се да је он ипак знатно удаљен од Европе, и то са културно-цивилизацијског становишта. Културно-цивилизацијска и језичка дивергентног Балкана директна је последица различитих језичких, културних, политичких, цивилизацијских и религијских уплива који су се вековима таложили на овим европским територијама и који су резултирали да се формирају три јасно оделите културно-цивилизацијске сфере (према француском научнику Бланку - зоне) између којих постоје како велике сличности тако и разлике. Савремена Европа се у последњих неколико деценија сусреће на својим географским подручјима са великом шароликошћу култура и цивилизацијских облика који су њој изворно непознати. Њихово прихватање или негирање постојања суштински се ни по чему не разликује од њиховог негирања и неприхватања на Балкану, но истина је та да се антагонизам у Западној Европи сагледава на други начин у односу на Балкан - док на Балкану антагонизам носи у себи јасан национално-религијски карактер, вековима продубљиван, усмераван и „посебно негован“, у Западној Европи он је превасходно тренутног економско-политичког па тек религијско-националног карактера.

Кључне речи: Балкан, европеизација, балканизација, балканскииндивидуализовани колективни идентитети

1 Рад је написан у оквиру пројекта Министарства НТР Републике Србије Језици и кулииуре у времену и йростиору, број 178002. 


\section{1. Уводно разматрање}

Све до почетка XIX столећа Балканско полуострво је било подручје без свог званичног имена, што имплицитно указује да за Западну Европу оно није било од важног геополитичког и геостратешког значаја. Чак су и сама сазнања о њему била прилично штура, контрадикторна и углавном погрешна. Довољно је, у том погледу, сагледати како је Балкан приказан у чувеној Дидроовој Енциклойеgији - у издању из 1751. године на страни 337. пише да се Босна и Херцеговина граничи с Албанијом (Дидро 1751, vol. ii: 337), а у издању из 1765. наводи се да је главни град Херцеговине Херцег-Нови (vol. viii: 187). Међутим, ни у XX столећу ситуација није била ништа боља, па тако, према Encyclopedia Britannica из 1911. године под Балканом се наводе следеће области: Албанија, Босна и Херцеговина, Бугарска, Хрватска и Славонија, Добруџа, Грчка, Илирија, Македонија, Нови Пазар, Србија и Румунија (EB, 1911: 259), док се у Encyclopedia Britannica Macropaedia из 1995. укључују у балканске државе Босна и Херцеговина, Косово, Македонија, Молдавија, Србија, Словенија, Румунија, Црна Гора и Хрватска, али се искључује Грчка.

За разлику од осталог дела Европе, највећи интерес за Балканско полуострво показивала су два царства - Аустријско, касније Аустро-Угарско, и Руско, свако са свог друштвено-политичког и економског аспекта. Аустријско, пошто је било на дохвату сировина преко потребних за развој индустрије, Руско, у својству „заштитника православних народа на Балкану“, желело је да прошири своју интересну сферу и да избије на Егејско и Медитеранско море како би могло парирати Енглеској и Францускоју геостратешком и геополитичком погледу.

Од XVIII столећа па надаље на Балкан су долазили бројни путописци и научници са запада Европе и захваљујући њиховим напорима учињен је први корак ка приближавању Европе Балкану. У међувремену су и балкански народи настојали да себе приближе Европи. Разлог томе је у чињеници да су сами балкански народи, односно њихови представници, схватили да уколико не ухвате корак с Европом, за којом су заостајали у техничко-технолошком, образовном и научном погледу, али не и у културно-цивилизацијском, остаће и даље на оном степену развитка из кога су желели да изађу. У Западној Европи 
балканско подручје је дуго било осликавано као територија на којој владају дивљаштво, хајдучија, варварство и примитивизам (Арнолд 1838-43: 492; Хобхаус, 1813: 585; Вокер, 1897: 252; Волш, 1836: 141). Чак је и чувени археолог сер Артур Еванс, после свог првог путовања по Балкану, тачније по Босни и Херцеговини 1875. године,разматрајући предео кроз који је требало да прође, назначио следеће:

Попели су ме на сасвим сигурног босанског коњића, те без икаквог другог смртоносног оружја осим штапа, запутио сам се са до зуба наоружаним пратиоцем у истраживање земље исто тако мало знане Европљанима као што је дивљина Азије. (Еванс 1878: 26).

Како је Анџел својевремено назначио, почетком XX столећа сматрало се крајње непристојним да углађен и доброћудан човек изусти реч Балкан у друштву или пред неким пацифистом (Анџеч 1912: 26). Уколико бисмо могли да пронађемо неку дефиницију Балкана која би могла да сублимира све оно што Балкан заправо јесте, онда смо мишљења да не постоји боља од оне коју је својевремено изнео Апворд - описујући Балкан, окарактерисао га је као „најмање познати ћошак Европе“ (the least-known corner of Europe; Апворд 1908: xvii).

\section{2. О Балкану са западноевропске тачке гледишта - негативно и позитивно}

Из претходно изнетог може се јасно увидети да постоје две потребе:

а) прва се тиче именовањанеке географске територије уз могућност њеног описа како би се ово именовање што адекватније обавило,

И

б) друга нужно задире у њено одређење у погледу класификовања (или категоризације) у већ постојеће друштвене, културолошке и цивилизацијске феномене.

У данашње време, посебно у оквиру постмодернистичких теорија и праваца, преовлађују многобројни (стручни) изрази чији је главни задатак да изоштре нашу свест о самој суштини карактера потребе 
стварања појмовних категорија као и о значају њиховог именовања. Такви су, на пример, појмови мапе ума (mental mapping), студије менталних и дискурзивних слика (имаїолоїија), симболичка географија, проучавање алтеритета (односно, другости) и слично. Балканско полуострво је, нарочито од периода туркократије, био доиста,удаљени ћошак“ Европе који се, како се касније видело, уклопио у приличној мери у турско-оријентални друштвено-политички и цивилизацијски миље (али не и сасвим религијски). Отуда није било никакве сумње за европски Запад како је Балкан, заправо, Оријент, или, боље речено, предворје Оријента. Другим речима, и само Балканско полуострво се уклопило на свој начин у схему оријентализма кога је палестински књижевник Едвард Саид у књизи Оријенйализам дефинисао на следећи начин:

Узимајући да би крај XVIII столећа био сасвим грубо дефинисан почетак од када се говори о оријентализму, оријентализам би се могао разматрати и анализирати као корпоративна институција зарад бављења Оријентом - бављење значи давање изјава о њему, његово описивање, насељавање, подучавање о њему, ауторизовање погледа о њему, владање њиме: укратко, оријентализам је био западни стил доминације, реструктурирања и имања превласти над Оријентом. (Саид 1978: 3)

Тако је Западна Европа себи пронашла одговарајући пандан мистични, недовољно познати Оријент постао је „оно друго“, њен својеврсни alter ego на основу кога је могла да уздигне свој властити идентитет и, наравно, своју премоћ. Имајући економску и политичку моћ, пре свегазахваљујући индустријској револуцији и напретку у свим гранама науке, Западна Европа је имала и могућност да ствара сопствено знање о оним областима које је тек требало открити или која су била недовољно позната и откривена, попут Балкана. Тиме што је Европа стварала сопствено (западноевропско) знање, покушавајући да приступи реално правом стању ствари на терену, истовремено је вршила различите класификације и дескрипције, настојећи да тиме колико-толико приближи друге светове себи и да их учини прихватљивим, разумљивим и људским. Истини за вољу, треба рећи 
да је у тим „реалним“ приказивањима било више ниподаштавања туђих култура, традиција и начина живота уз пристрасно величање властите културно-цивилизацијских домена, успеха као и религијске основе. У том смислу довољно је сетити се речи немачког канцелара Бизмарка изговорених у Рахстагу 1876. године како „Балкан не вреди нити малог прста нити здравих костију иједног мускетара из Помераније“. Бизмарку се приписују и две карактеризације Грка и Срба: док је ове прве бритко одредио као „најординарније лопове оваца“, за ове друге је изјавио: „Ако у Србији сретнете човека који носи кошуљу преко панталона, можете се у њега поуздати. То је честита и поштена људина. Ако, међутим, кошуљу упасује у панталоне, он постаје лопужа““.

У представама од средине XIX столећа па све до наших дана Балканско полуострво се посматра кроз низ амбивалентних именовања (термина, назива) чији је задатак да овај део Европе, са једне стране, непосредно приближи Европи, а са друге да покаже колико је он од ње саме веома различит. Такви су метафорички описи Балкана, попут ,раскрсница Европе“, „спој Истока и Запада“, „граница између Истока и Запада“, ,размеђа двеју цивилизација“ и слично, што недвосмислено говори у прилог тези како Балкан нити је „Европа“ нити је „Исток“, нити је цивилизација (у западноевропском погледу) нити је прави Оријент. Заправо, Балкан је нешто између и то „између“ одувек је било тешко и правилно дефинисати, превасходно због његовог посебног положаја у општем европском културно-цивилизацијском окриљу. Како није права Европа, али вуче много на Исток, Балканско полуострво је постало делом Истока, тачније речено Источне Европе која је, као појам и термин, настала у време просветитељства. Према речима Лерија Волфа,

Западна Европа је измислила Источну Европу као своју комплементарну другу половину у XVIII столећу, Веку просвећености. Такође је просветитељство, са својим интелектуалним центрима у Западној Европи, који су неговали и присвојили за себе нов појам 'цивилизације', неологизам XVIII столећа, и цивилизацијом, открило свој комплемент, унутар самог континента, у мрачним пределима назадњаштва, па и варварства. Тако је измишљена Источна Европа. (Волф 1994: 4) 
Шта би била, у краткој суштини, одлика свих тих представа? Тиме што је пронађен пандан, Западна Европа је желела да скрене пажњу са себе на оног другог. Све што њој није одговарало, или чега се желела на неки начин ослободити, приписивала је по аутоматизму другој страни, почев од апсолутизма у власти, деспотизма, личне самовоље преко аутархије, примитивизма, неукости и демагогије па до економске заосталости, политичко-парламентарне неразвијеност те свеопште цивилизацијске назадности (овде мислимо на техничко-технолошки напредак). У културном погледу, међутим, Западна Европа није имала шта много да приговори Источној Европи, пошто је ту Исток безмало на равноправној основи парирао Западу. Баш због таквих изграђених стереотипа о Балкану, и о Балканцима, Балкан је временом постао синоним за све оно што није добро, па тог разлога не треба да чуди и даље тврдокорно одбијање Хрвата да признају како је Хрватска делом и балканска држава.

Позитивна виђења о Балкану, која, нажалост, нису тако бројна, појавила су се нешто касније, али историјски релативно брзо. Ту су посебну улогу имали романтичари, понајпре Бајрон и филхеленски покрет у Великој Британији, чији су снажни импулси надахњивали европске филхелене. Но, чињеница је да је и Бајрон, попут многих других филхелена, био прилично разочаран директним сазнањем како су Грци његовог доба имали тако мало заједничког са својим славним античким прецима. Позитивне конотације о једном балканском народу могу се пронаћи и у веома утицајном памфлету Вилијама Гледстона (William Ewart Gladstone, 1809-1898), британског либералног политичара, под насловом Ужаси у Буїарској и истиочно иичйање (Bulgarian Horrors and the Question of the East) из 1876. године у коме је гневно описао немилосрдни масакр вандалских Османлија над невиним Бугарима. У том памфлету, употребљавајући сва расположива оружја реторике, негативно је приказао Турке и отворено се сврстао на страну жртве, жестоко критикујући Дизраелија и његове политичке потезе.

Временом се искристалисао и позитивни такозвани мотив „племенитог дивљака““ који је, посебно у борби, неговао витешке елементе одавно превазиђене и заборављене у Западној Европи. Чини се да су управо ту страну прво приказали Вукови записи српских народ- 
них јуначких песама а нешто касније и примедбе немачког географа, историчара и путописца Јохана Кола (Johann Georg Kohl, 1808-1878) са путовања по Црној Гори 1850. године:

Већина обичаја и навика Црногораца заснива се на прастарим узорима, То су обичаји и навике који су овде на старом словенско-грчком полуострву вероватно већ много пре Хомера владали и који су се овде међу овим планинским и пасторалним народима или од Деукалионових времена добро очували или уз мање промене увек наново репродуковали. Верујем да се у свакој појединачној особини која одликује Црногорце може открити и нека особина код хомерских јунака као паралела. (Кол 1851: 300-301).

Без обзира на то што је Балкан већ био окарактерисан негативно као Оријент, управо је његов оријентални карактер био за поједине путописце извор истинског одушевљења и заноса. Тако, на пример, амерички писац Хауден Смит (Arthur Douglas Howden Smith, 18871945) је у опису Софије дао и следеће:

Софија није у потпуности цивилизована да би изгубила свој староставни шарм, својумирисну арому Истока. Оличење цивилизације је тек незнатно у неким сегментима, док у другим готово да нема неке вредне разлике. Осећате инстинктивно, док ступате са степеница возана перон мале, уредне, жуте станице у Софији, да је Европа иза вас; стојите у сенци Оријента. (Смит 1908: 9).

Док је Стокеров Дракула знатно утицао да се у Западној Европи рашири прилично негативна слика о Румунима као о вампирима, вукодлацима и крвопијама, дотле је једно позитивно виђење Балкана, или барем једног његовог дела, покушао да пружи Карл Maj (Karl Friedrich Мау, 1842-1912) својом пустоловном причом Кроз земљу Скииетиара (Durch das Land der Skipetaren, 1892) којом је бацио посебно светло на ово подручје европског Оријента. Колики је утицај то дело имало на немачку научну свест, огледа се у чињеници да је све до друге половине XX столећа у званичном оптицају био етноним Скипетари уместо Албанци. Нажалост, чињеница је да Мај није од- 
ступио од већ устаљене стереотипне слике приказивања Албанца (па и Балканца) - и поред тога што живи у сиромашној, примитивној и прљавој земљи, Албанца красе бројне позитивне и негативне особине: позитивне се огледају у срчаности, оданости отаџбини, жељи за слободом духа и независношћу, националном заједништву у борби против непријатеља, док се негативне виде у насиљу, слепој мржњи, окрутности, осветољубивости, исламском фанатизму, подмитљивости, неповерењу, непоштовању закона итд.

\section{3. Европеизација Балкана}

Ратови у бившој Југославији, умногоме подстакнути наслеђеним и, само донекле потиснутим, национално-националистичким идејама из XIX столећа, могу се посматрати као резултат директног уплива такозване „европеизације“ Балкана, односно делова Османлијског царства који су временом стицали своју независност, међународно признање и територијално проширење. Супротно свим очекивањима, Балкан је вековима био једини део европског континента који се заиста могао подичити најширим обликом толеранције према другим народима, религијама, различитим културама као и према бројним етничким и мањинским заједницама. Народи на Балкану, далеко пре оснивања покрета несврстаности, знали су шта значи принцип „активне и мирољубиве коегзистенције” живећи у мултикултуралном и мултилингвалном миљеу много пре него што је то постала „мода“ на западу Европе, па и шире. Разлог таквог стања крио се у томе да су данас већински народи некада били у инфериорном положају односу на Турке и остале припаднике мухамеданске вероисповести. Делећи потпуно исту судбину у националном, друштвеном, економском и политичком погледу, балкански су народи унутар Османлијског царства били принуђени да живе један поред другог у једној врсти мирољубиве коегзистенције. Као можда најбољи пример те коегзистенције могао би послужити запис данасамеричког сликара Лестера Хорнбија (Lester George Hornby, 1882 - 1956) који је почетком 20-тих година прошлог века посетио Краљевину Срба, Хрвата и Словенаца. Тако, описујући свој боравак у Сарајеву, за око му је запало то што у граду живе и раде Срби, Муслимани и Јевреји једни уз друге, па се са пра- 
вом запитао „да није можда толеранција једна од највећих врлина“ (Хорни 1927: 153). Током читавог ХIX столећа, који се може посматрати као век балканског друштвеног, политичког и националног ослобођења, али и као век савремене културне те цивилизацијске еманципације свих балканских народа у већем или мањем степену, управо су се мирољубивна коегзистенција и толеранција између балканских народа нашле прве на удару. Тиме је отворена Пандорина кутија чије последице и данас осећамо на свим пољима живота и рада. Од тренутка када су млада балканска друштва усвајила принцип либералног капитализма и демократије, са једне стране, те принцип формирања властите националне државе, са друге, уздрмани су темељи тих односа вековима изграђивани у једном сасвим другачијем духуи погледу.

Чини се као да је на сцену наступила свеукупна ретроградизација односа која је до те мере отишла у погрешном правцу да је свега неколико година после званичног признања постојања независности Бугарске и Србије на Берлинском конгресу већ вођен рат између ових балканских држава (1885). Додатни парадокс може се сагледати у оквиру најновије историје односа балканских народа - док су они нашли заједнички интерес да се организују и да заједничким снагама поведу Први балкански рат, мотивисан жељом да се једном за свагда стави тачка на турско присуство на Балкану, односно на оним територијама и даље у склопу Османлијског царства, а које су се сматрале националним, пре свега из историјских разлога, дотле је Други балкански рат можда најбољи пример како је сваки трајнији, непосреднији и чвршћи вид сарадње између балканских народа апсолутно неодржив и немогућ.

Стална потреба да се Балкан приближи Европи огледа се и у реторици балканских језика: у српском постоји одомаћен израз срйска/ балканска йосла који има свој пандан у у бугарском само у форми

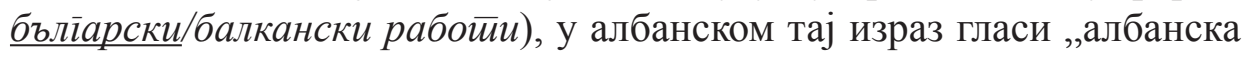
посла" (punë shiptare), док је у македонском и грчком устаљен израз

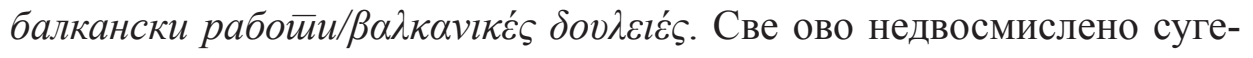
рише како је реч о нашим, дакле „домаћим” (локалним), обичајима који, као такви, нигде другде не постоје. У бугарском се још додатно прави дистинкција - насупрот овом изразу стоји израз йо евройейски који означава све оно што треба да се ради на савремен, тачан и ефикасан начин. Док се у Србији и шире на аутобуским станицама 
купују карте према Европи, односно за европске дестинације, дотле у Софији и даље међународни аутобуси крећу „за Европу”, што је готово истоветно са стањем ствари средином XIX и прве половине XX столећа када су млади одлазили у Евройу - најпре у Беч, потом у Будимпешту и Праг - на високе школе. Интересантна је у том погледу студија Евгеније Крстеве-Благоеве из 2003. године у којој се уочава податак да је већина младих Бугара и Бугарки, њених информатора, истакла како „ми још нисмо постали Европљани”, и поред чињенице да је Бугарска у том тренутку иформално била на прагу да постане пуноправна чланица Европске Уније (Карстева-Благоева 2003).

У покушајима европеизације Балкана додатну улогу су играли (и даље играју) снажни балкански национални идентитети. Почетно су се они према европском идентитету, дакле према идентитету цивилизованог човека, постављали као инфериорни, нижеразредни, приказивани су безмало као „нецивилизовани”. Чак и данас балкански народни идентитети нису много одмакли од тих почетних поставки. Отуда је за сваки балкански народ било од посебне важности проналажење свог „исконског и правог европског” корена и приближавање Европи. У том процесу су се мање или више ломиле традиције, што је било неминовно. Како је приметила Милица Бакић-Хејден (Бакић-Хејден/ Хејден 1992), ова супротност између балканског и европског идентитета, између „нецивилизоване” и „цивилизоване” поларности, довела је до тога да се јаве отпори према свему што је балканско и „нецивилизовано”. Овај процес је назвала уїнежgеним оријенйализмима (nesting orientalism). Током распада бивше Југославије то се најбоље видело на делу - Хрвати и Словенци одбијали су да се приклоне балканском културном окружењу, инсистирали су на својој европској усмерености и на својим дубоким европским (тачније хабзбуршким) традицијама, затим на принципима демократије и парламентаризма, а све ово је додатно било подвучено и преко припадности римокатолицизму. Ова поларизација се налазила у оштрој супротности са поларизацијом „оних других" са којима нису желели више суживот; дакле, с онима који су поседовали све одлике „оријенталног“ (тј. балканског, другоразредног) карактера, што ће рећи да су „назадни“, „насилни“, „недемократски“, „непоуздани“ и друге вероисповести. Међутим, можемо приметити да се код Срба и Грка, на пример, угнежедни оријентализам огледа у 
чињеници да они себе заиста доживљавају као европске народе који се и даље налазе у отвореном сукобу са мухамеданством. Код Грка се још додатно потенцира на томе, посебно уколико имамо на уму да је Византијско царство била прва европска држава која је покушавала вековима да се одупре најезди Турака у Европу.

У поступку европеизације Балкана на сцену су нужно ступили балкански индивидуализовани колективни идентитети (Мутавџић-Кампурис 2013: 140) који су и даље веома активни. Њихова улога огледа се у томе да сваки балкански народ, у процесу доказивања свог (про)европског порекла и стремљења, покушава да се на неки начин удаљи или чак одрекне заједничких балканских (превасходно језичких, културних, донекле и историјских) темеља, да их сасвим занемари или, уколико није могуће ништа друго, да их ублажи у највећем степену, модификујући их и пружајући им ново значење и (про)европски карактер. Ово се посебно види на јужнословенском подручју, мада ни грчко ни албанско, па ни румунско, није имуно на модификације овога типа. На пример, колико је жеља за европеизацијом Хрватске била важна рефлектовала се и у томе што се у Хрватској пред туристичку сезону 2007. године поставило питање да ли страним гостима у Далмацији треба понудити јела са роштиља која нису аутентична хрватска (sic!) јела.У те расправе укључила се била и хрватска академска јавност, политичари као и Институт за хрватски језик и књижевност који је предложио нову реч за роштиљ - жаропек. На крају је ипак победио здрав разум угоститеља који су истакли да је роштиљ нешто што је остала традиција после безмало осам деценија живота у бившим Југославијама, да је сасвим природно што су та јела већ у јеловницима те да и сами странци већ знају шта треба да наруче.

\section{4. Примарна и секундарна балканизација Балкана}

Сагледано са културно-цивилизацијске тачке гледишта, поремећеност односа између балканских народа наступила је током формирања савремених балканских држава када се код сваког балканског народа појавила тежња за историјско, културно и национално преиспитивање властитих корена и властите самобитности.Отворена жеља да се поврати оно што је некада изгубљено на друштвеном и тери- 
торијалном плану била је редовно праћена величањем и истицањем властите националне историје ивластитог националног значаја, уз потенцирање националне самосвести, што се каткад граничило и изједначавало са национализмом. У таквој клими истицање властитог права пречег на неки део територије у односу на други народ, уз често чак проглашавање и својатање туђе историјске територије као своје унутар властитог историјског националног контекста, довели су до тога да се балкански народи окрену један против другога, што се, у једном ширем контексту, може посматрати као секундарни облик балканизације.

Примарна балканизација се одвијала на два важна нивоа:

a) први се огледао у засебним национално-ослободилачким ратовима против Турака, уз свесрдну подршку и сагласност великих европских сила,

б) други се рефлектовао у константном прекрајању државних граница балканских народаи у ширењу територија балканских држава на рачун већ прилично ослабљеног Османлијског царства.

Према нашем виђењу, секундарна балканизација, за коју су балкански народи добијали подршку сепаратну великих сила из различитих разлога и у различито време, директна је последица неколико кључних елемената:

a) На првом месту истичемо нагомилане национално-политичке, територијалне, друштвене, културне и донекле религијске тензије између балканских народа које су се појавиле у тренутку када је борба против Турака зашла у једну мирнију (спорију) фазу одвијања и када се поставило питање демографских граница распростирања сваког балканског народа. Тако је, на пример, Вук Караџић правилно осетио да се на територији од Ниша до Пирота, Врања и Беле Паланке не говори бугарски језик и да је не одликује бугарска национална свест, како су описивали и приказивали бугарски истраживачи Иванов, Исирков и Романски (Стоян Романски, 1882-1959). Вук је жестоко оспорио и наводе бугарског патриоте Филаретова (Сава Вълчев 
Филаретов, 1825-1863) који је у свом подробном списку Граgове въ Бъліария,иначе састављеном на Вукову молбу како би Вук имао јаснији увид у географију Бугарске, дао деведесет шест имена градова и насеља у којима су живели једино Турци и Бугари. Према Филаретовој статистици, у Нишу је живело само 3.000 Турака и преко 5.000 Бугаpa, а у Приштини је постојало свега 600 кућа, од којих је једна трећина била чисто бугарска, преостали део био је изразито албански.

б) На другом месту су тежње за приближавањем европском Западу како у техничко-технолошком погледу (у виду модернизације, европеизације и индустријализације) тако и у културно-цивилизацијском погледу, посебно у погледу прихватања свих новина, праћења моде, начина опхођења итд. Ово приближавање имало је и свој додатни циљ - да покаже како балкански народи, и поред тога што је облик њиховог културно-цивилизацијског окружења другачији, ипак нису без своје богате и разноврсне културно-цивилизацијске традиције. Колико је и даље снажна потреба за културно-цивилизацијским приближавањем Балкана Европи и свету, најбољи пример представља све чешћи случај да се у ма ком већем граду Балкана или у туристичком месту све теже може наручити турска кафа, док су је готово листом у ресторанима и кафићима замениле кафе далеко звучнијег („европског“ и „интернационалног“) порекла. А уколико којим случајем постоји турска кафа у понуди, онда се она јавља на српском терену у виду два еуфемизма - „домаћа” или „кувана кафа”. У Хрватској, на пример, у последње време нико не наручује јавно турску кафу, али зато је сви (или безмало сви) приватно пију.

в) Трећи важан елемент чини распиривање етничког антагонизма који, према Елису и Рајту, апострофира [властити] етницитет (Елис/Рајт 1998: 690) и који тако постаје главни камен спотицања у односима између балканских народа.

г) Као четврти фактор јесу појаве нових (или, условно речено, нових) етницитета, у облику мањина или етничких група/заједница, који легално и легитимно траже своја национална правауправо по угледу на права која уживају припадници већинског становништва. 
д) Пети чинилац секундарне балканизације огледа се у спречавању мањина и других заједница на територијама балканских држава да задрже свој културни, језички и етнички идентитет тако што се подвргавају систематској и отвореној асимилацији у већинско становништво (такав је случајданашњих Горанаца на Косову, Турака (такозваних Помака) у Бугарској те Аромуна у Албанији и у Грчкој). За балкански друштвени простор карактеристично је то да се проблем мањина посматра искључиво као унутрашњи проблем, без потребе за његовом интернационализацијом.

Секундарна балканизација је, према нашем мишљењу, последица још нечега о чему се само узгред говори - недостатка културе комуникације између балканских народа, а што је донекле парадоксално, ако имамо у виду да је њихов културно-цивилизацијски миље препознатљив у мањој или већој мери. Иако су Западна Европа и Балкан саставни део европског континента, они су оштро раздељени између себе управо у назначеном контексту. Запад се, међутим, културом комуникације и парламентаризмом не може подичити као традиционалним, јер не треба заборавити да су западноевропски народи ратовали између себе врло често све до 1945. године. Тачно је да се енглески парламентаризам негује још од 1264, када је први пут званично сазван парламент, али је тачно и то да су европски народи тек од завршетка Другог светског рата схватили да се са старим системом не може ићи напред и да је потребно да предузму одређене кораке у том правцу. Како је њихову комуникацију отежавало историјско бреме и разни атавизми из прошлости, покушали су да их оставе по страни и да се усмере ка будућности и ка изградњи порушене Европе. Кључни интерес су пронашли у економији и у привредној сарадњи. Без обзира на све, може се рећи да су европски народи закопали ратне секире, постепено научивши да то што живе једни уз друге није питање ни културно-циливилизацијског престижа, ни националног поноса, још мање односа између „изабраног народа” и „оних осталих”, већ да је реч о томе да смо сви обични људи које, како је велики Шилер назначио у Ogu pagoс $\bar{u} u$, у 
Радости снове вежу нити,

Што растави мода зла.

Сви ће људи браћа бити,

Крило твоје спајат' зна.

Да би дошло до спајања и да сви постану браћа, било је неопходно да народи на западу Европе, различити и по карактеру, и по менталитету, и по религији савладају вештину културе комуницирања и међусобног уважавања. Овај нимало лак задатак још није приведен крају.

Балкан, за разлику од осталог дела Европе, нуди оно што би се могло окарактерисати као „европска другост” у форми алтернативног културно-цивилизацијског идентитета и менталитетаособито видљивог уразличитим формама фолк-музике коју балкански народи поносно истичу као властито етно обележје. Без обзира на локално именовање ове музике (новокомйонована нарояна/йурбо-фолк, новокомйонирана фолк музика (мак.), tallava (алб.), чалїа или чалїја (буг. чалгия), manele (рум.manele), גaїкó (грчки), Балкан није, ма колико споља изгледао, јединствен ни у историјском контексту ни у културној позадини (Рихтман/Аугуштин 1997: 34) - како је он спој нагомиланог вишемиленијумског историјског, културног, цивилизацијског и религијског наслеђа, које је довело до тога да се временом појави такозвани „балкански културно-цивилизацијски израз“, Весна Голдсворти је с правом овај део Европе назвала „пупком континента“"2 (Голдсворти 1998: 78). Нажалост, овај „пупак континтента“ још није пронашао свој комуникацијски modus operandi. Премда се он сада постепено ствара под снажним утицајима и притисцима из Западне Европе, да којим случајем могу бирати, балкански народи би радо избегли да разговарају и преговарају између себе. То се посебно види у медијацији коју је преузела на себе Европска унија, покушавајући да наведе и српску и косовско-албанску политичку страну на преговоре. У оквиру тих преговарачких процеса од значаја је приметити како се променила званична реторика, па се тако у медијима у Србији више не могу

2 Мада се њена синтагма изворно везује за подручје Трансилваније, сматрамо да нећемо много погрешити уколико семантички проширимо ово виђење на цело Балканско полуострво које је и мултикултурално и мултилингвално. 
прочитати или чути синтагме попут „самозвана република Косово“, „нелегални органи власти“, „самопроглашено Косово“, „непризната влада Косова“, већ да су се разговори између „премијера Србије и Косова одвијали на највишем нивоу“, или да се успоставља „нормализација односа између Београда и Приштине“, или да су „Србија и Косово равноправни партнери у преговорима“. На сличан начин пишу и извештавају медији на Косову и Метохији већ дуже време, на пример: „преговори између Косова и Србије настављају се ради нормализације односа између две земље“ (,,bisedimet midis Kosovës dhe Serbisë vazhdojnë për normalizimin e marrëdhënieve midis dy vendeve").

Бугарски културолог Кјосев (Kiossev, 2002: 185) одупирање негативним стереотипима о Балкану, односноодупирања секундарној балканизацији, сагледавау такозваним контракултурним стратегијама које су се појавиле у једном масовнијем обиму од 90-тих година прошлога столећа. Ове стратегије су видљиве у свим новим облицима масовног укуса који је старим садржајима подарио нов дух и нов смисао. Као можда најбољи пример контракултурне стратегије Кјосев наводи балканску народну музику која је, посебно преко филмова Емира Кустурице, ушла на велика врата у Европу и шире и која пружа једну сасвим другачију слику о Балкану у односу на ону уврежену. Нешто слично могуће је приметити и када је реч о Драгачевском сабору трубача који је, као посебно откриће, постао светски хит у последњих неколико година како у Европи тако и у свету.

\section{5. Уместо закључка}

Неоспорна је чињеница да је до почетка XIX столећа за Западну Европу Балкан био прилично непознато подручје које је почело да се интензивно и постепено открива и проучава са различитих аспеката током следећа два века. Оно што су и путописци и бројни научници од почетка приметили јесте како је Балкан, са једне стране, веома близак Европи - овде се, пре свега, узимала у обзир географска близина, али да је он, са друге стране, знатно удаљен од Европе, уколико се посматра са културно-цивилизацијског становишта. Културно-цивилизацијска и језичка дивергентног Балкана директна је последица различитих језичких, културних, политичких, цивилизацијских и ре- 
лигијских уплива који су се вековима таложили и који су резултирали да се формирају три јасно оделите културно-цивилизацијске сфере између којих постоје како велике сличности тако и разлике. Француски научник Андре Бланк ове сфере разматра као зоне културног деловања које именује као византијска, германска и медитеранска (Бланк 1965: 35). Свака од ових зона одговара некадашњим доминантним политичким снагама, при чему се у оквиру медитеранске зоне осећа и данас утицај Венеције и Италије, донекле и Дубровачке Републике, а у оквиру германске утицај Аустро-Угарске монархије. За разлику од њих, византијска културно-цивилизацијска зона није монолитна, будући да се у њој временом издвојила посебна подзона, исламска, која је постала носилац оријентализма, односно неооријентализма (Куркела 1997: 187) у последње три деценије. Зато Превелакис исправно каже како „Балкан за географију постаје све више тема него велика регија ... [која] најпре постоји у духовима а потом на терену“ (Превелакис 1994: 17). Другим речима, према Голдсвортијевој, „балканизација Балкана се наставља баш због тога што се 'Балкан' увек односи на нешто друго него на нас саме“ (Голдсворти 1998: іх).

Савремена Европа се у последњих неколико деценија сусреће на својим географским подручјима са великом шароликошћу култура и цивилизацијских облика који су њој изворно непознати. Њихово прихватање или негирање постојања суштински се ни по чему не разликује од њиховог негирања и неприхватања на Балкану, но истина је та да се антагонизам у Западној Европи сагледава на други начин у односу на Балкан - док на Балкану антагонизам носи у себи јасан национално-религијски карактер, вековима продубљиван, усмераван и „посебно негован“, у Западној Европи он је превасходно тренутног економско-политичког па тек религијско-националног карактера. Без обзира на све, будући да је суживот балканских народа неминован и у будућности, ради заједничког останка и опстанка на овим европским територијама дубоко верујемо да не преостаје ништа друго и садашњим и наредним генерацијама него да се озбиљно посвете савлађивању принципа како интеркултуралне комуникације тако и културне комуникације како би се унапредили и поспешили сарадња и разумевање између балканских народа са главним циљем - да се у што већој мери уклоне препреке које су сами беспотебно изградили и поставили између себе самих. 


\section{Литература}

Бакић-Хејден/Хејден 1992: Milica Bakić-Hayden / Robert Hayden, „Orientalist Variations of the Theme „Balkans“: Symbolic Geography in recent Yugoslav Cultural Politics“. Slavic Review 52:1 (1992): 1-16. Бланк 1965: André Blanc. Géographie des Balkans. Paris: PUF.

Анџел 1912: Norman Angell. Peace Theories and the Balkan War. London: Horace Marshall \& Son.

Дидро: Denis-d'Alambert Diderot, Jean le Rond. Encyclopedie, ou Dictionnaire raisonné des sciences, des arts et des métiers. Paris, 1751-1765.

EБ: The Encyclopedia Britannica, Vol. III, $11^{\text {th }}$ Edition. Cambridge: Cambridge University Press, 1911,258-261.

Еванс 1878: Arthur J. Evans. Illyrian Letters. London: Longmans, Green and Co. Елис/Рајт 1998: M. Ellis / R. Wright, "The Balkanization Metaphor in the Analysis of U.S. Immigration". Annals of the Association of American Geographers, 88(4), (1998): 686-698.

Голдсворти 1998: Vesna Goldsworthy. Inventing Ruritania: The Imperialism of the Imagination. New Haven-London: Yale University Press. Xобxayc 1813: John C. Hobhouse. A Journey through Albania and Other Provinces of Turkey in Europe and Asia. London: J. Cawthorn.

Хорнби 1927: Lester George Hornby. Balkan Sketches.An Artist's Wanderings in the Kingdom of the Serbs. Boston: Little, Brown and Company. Карстева-Благоева 2003: Evgenija Karsteva-Blagoeva. „Who Are We? Types of Collective Identities in Contemporary Bulgaria“, Ethnologia Balkanica 7 (2003): 89-106.

Kjoceв 2002: Alexander Kiossev, „The Dark Intimacy. Maps, Identities, Acts of Identification“. In Dušan I. Bjelić-Obrad Savić (eds.) Balkan as Metaphor. Between Globalization and Fragmentation. Massachusetts: MIT, 2002,165-191.

Кол 1851: Johann Georg Kohl. Reise nach Istrien, Dalmatien und Montenegro. Band I. Dresden: Arnoldische Buchhandlung, 1851.

Куркела 1997: Vesa Kurkela, "Music Media in the Eastern Balkans:

Privatised, Deregulated and Neo-Traditional", Cultural Policy 3 (2),(1997): 177-205.

Мутавџић/Кампурис 2013: Предраг Мутавџић / Anastassios Kampouris. „Интеркултуралност и мултикултуралност савременог Балкана 
(језички и културни идентитет Балкана)“. У: Наука и савремени

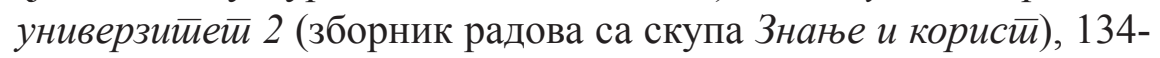
144. Ниш: Философски факултет.

Превелакис 1994: Georges Prévélakis. LesBalkans. Culture et géopolitique. Paris: Nathan.

Рихтман-Аугуштин 1997: Dunja Rihtman-Auguštin, "Zašto i otkad se grozimo Balkana?“ Erasmus 19 (1997): 27-35.

Саид 1978: Edward Said. Orientalism. New York: Vintage Books.

Смит 1908: Arthur Douglas Howden Smith. Fighting the Turks in the Balkans: An American's Adventures with the Macedonian Revolutionaries. New York-London: G.P.Putnam's Sons.

Апворд 1908: Allen Upward. The East of Europe. London: John Murray,. Вокер 1897: Mary A. Walker. Old Tracks and New Landmarks.London: Richard Bentley and Son.

Волш 1836: Robert Walsh. A Resistance at Constantinople. London: Henry Colburn,.

Волф 1994: Larry Wolff. Inventing Eastern Europe.The Map of Civilization on the Mind of the Enlightenment. Stanford University Press. 


\title{
Predrag Mutavdžić \\ Anastassios Kampouris
}

\author{
Summary \\ THE BALKAN PENINSULA THROUGH THE PRISM \\ OF EUROPEANIZATION OR EUROPE THROUGH \\ THE PRISM OF BALKANISATION? \\ (A CONTRIBUTION TO THE STUDY OF CULTURAL \\ RELATIONS BETWEEN THE BALKANS AND EUROPE)
}

An undeniable fact is that by the beginning of the 19th century for Western Europe the Balkans were quite an unknown area which was extensively and gradually being examined and (re)discovered from various aspects during the next two centuries. From the very beginning it was noted by the first travellers but also numerous scholars that the Balkans, on the one hand, as a territory is very close to Europe - in general, geographical proximity was primarily taken into consideration, but at the same time this region is much more distant of Europe, particularly from cultural and civilizational points of view. Cultural-civilizational and linguistic diversities of the Balkans are a direct consequence of different linguistic, cultural, political, historical and religious influences which had been accumulated in this European territoriy for centuries and which finally resulted in a form of three clearly separated cultural and civilizational spheres (according to the opinion of French scientist Blanc - zones) which are as much similar as different. In its geographical territories in the last few decades modern Europe has encountered a huge diversity of cultures and forms of civilization originally unknown to them. Their acceptance or denial of their existence does not essentially differ from their denial and rejection in the Balkans, but the truth is that the antagonism in Western Europe can be seen in a different way in comparison with the Balkans - while in the Balkans antagonism usually carries a clear national-religious character, carefully directed and "especially cultivated" for centuries, in Western Europe this antagonism is primarily based on the current socio-political tendencies rather than on religious-national character.

Key words: The Balkans, Europeanization, balkanization, individualized collective identities of the Balkans 